No mention of the T.C.D. School would be complete without reference to the red-headed lad, Joe Murray, who appeared in 1905-6 and remained there until his death on January 24 of this year. With the professor, "Joe", Wild and Polly, head of the College groundsmen, I spent many happy years.

The delightful atmosphere of our chief's laboratory could be traced back to the home with his mother and sisters-enlivened by frequent visits from his brothers and their families. It was the same in his own home with his wife, who cared for him with such devotion. I recall his happiness when telling me that their three sons (all of whom have had distinguished careers) had never caused him one moment's anxiety.

W. R. G. Atrins

\section{Mr. R. S. Whipple}

IT was with a deep sense of loss that his large circle of friends heard of the death of Robert Stewart Whipple, which occurred at his home in Highgete Village on Sunday, December 13. His father, G. M. Whipple, was superintendent of the Kew Observatory, and was himself very interested in scientific instruments. Thus Whipple grew up with scientific instruments and acquired $a_{0}$ love for them which coloured his whole life.

Whipple was educated at King's College School, Strand, and on leaving went in 1888 directly into the Kew Observatory, staying on for three years after his father's death in 1893 with his successor, Dr. Charles Chree. In 1896 for two years he was assistant manager to L. P. Casella, and then he joined the Cambridge Instrument Company, which Horace Darwin in partnership with A. G. DewSmith had founded in 1881. In 1909 Whipple and C. C. Mason became joint managing directors. Under their management the firm developed and acquired a high reputation for the quality of its products. Of these, mention may be made of the 'rockingmicrotome', a piece of beautiful design by Sir Horace Darwin, and $a$ range of temperature-measuring instruments. Whipple was responsible for the introduction of the Fery radiation recorder, of which the firm bought the rights for Great Britain. He himself designed an instrument for reading temperatures direct on the gas-scale; this is used largely to-day in industry as a sub-standard.

He retired from active management in 1935 , but remained a director, and in 1939 was elected chairman of the Board; from this he retired in 1949 for reasons of health, but continued to take a keen interest in the firm. During all this time he took a great personal interest in the employees of the company, which they fully reciprocated, feeling that in him they had a sincere friend.

Whipple was a valued member of the societies connected with physics and a constant attendant at their meetings. He was a member of the Council of the Physical Society during $1909-14$ and again during 1925-36, a vice-president from 1914 until 1916 and treasurer from 1925 until 1935 . He was president of the Optical Society in 1920-22. He was a. founder member of the Institute of Physies in 1920 , and served on its Board for a total of twentyone years between 1920 and 1945, and on its Finance Committee from 1945 onwards. His services in the cause of physics received their highest recognition in his election to the presidency of Section A (Mathematics and Physics) for the Dundee meeting of the British Association in 1939, which, however, was abandoned due to the outbreak of war-one of the few cases in which that honour has fallen to an industrialist.

Whipple was always interested in the history of science and was $a_{6}$ collector of early scientific instruments; of these he built up a wonderful collection which he most generously presented to the University of Cambridge in 1944 ; but it was not until 1951 that a small building was provided for their display, and the Whipple Museum was opened by the ViceChancellor on May 5. Now that "History and Philosophy of Science" has (partly perhaps due to the inspiration of this Museum) been included as a half-subject in the Natural Sciences Tripos, candidates will find the study of the actual instruments, that this Museum affords, of very real help. When the plans for the new Science Laboratories at Cambridge are further advanced, it is to be hoped that a larger building will be found, in whioh, with the Whipple instruments as a nucleus, the great number of instruments that Dr. R. T. Gunther proved to exist in Cambridge by the collection he was able to get together in June 1936 will again be sssembled to grow to a collection worthy of the University.

In addition to the instruments, Whipple gave his library of scientific books, which included many of the rare early ones. $\mathrm{He}$ hoped that these might eventually be housed near the instruments, so that an instrument and its description can be studied together.

He also handed to trustees a fund of $\$ 3,300$-later increased to $£ 8,300$ - to be used for the purchase of instruments and books.

Whipple was a man of wide interests and engaged in many activities, serving on many committees; these will miss his wise guidance and support - often of $\&$ substantial kind. He will long remain in the hearts of those who served with him.

In 1939 he was elected president of the Highgate Literary and Scientific Institution, into which he put new life by his energy and help, and it is now a strong society. Only a little more than a week before his death, he gave the sum of $£ 5,000$ to trustees to be used for the benefit of Highgate Village.

Whipple was a fine example of an English gentleman, upright and honourable, full of kindliness and sympathy, ready to help in any good cause and a man of wise counsel and sound common sense. He had great charm of manner which endeared him to all with whom he came into contact. $\mathrm{He}$ married Helen Muir, daughter of a Glasgow engineer and sister of James Muir, professor of natural philosophy in Glasgow; they celebrated their golden wedding in June 1953. Their son, George, is chairman and managing director of Messrs. Hilger and Watts, makers of optical scientific instruments, and a daughter, Ruth, is the wife of Prof. J. F. Young, professor of pathology in the University of Aberdeen.

\section{R. S. CLAY}

$W_{E}$ regret to announce the following deaths :

Mr. P. S. Ridsdale, director of the Charles Lathrop Pack Forestry Foundation, formerly editor of the American Forestry Magazine (1912-22) and of Nature Magazine (1923-37), on December 23, aged eightyone.

Mr. H. W. J. Stone, honorary secretary and treasurer during $1933-45$ of the Parliamentary Science Committee and editor of its publication Science in Parliament, on January 17, aged seventy-six. 